\title{
Article \\ Values Underlying the Information Culture in Communist and Post-Communist Russia (1917-1999)
}

\author{
Hedwig de Smaele \\ Faculty of Social Sciences, KU Leuven, Campus Brussels, 1000 Brussels, Belgium; \\ E-Mail: hedwig.desmaele@soc.kuleuven.be
}

Submitted: 27 May 2015 | In Revised Form: 24 August 2015 | Accepted: 5 October 2015 |

Published: 29 December 2015

\begin{abstract}
In this article the concept of information culture-understood as the dominant handling of information, shared by a dominant proportion of journalists, the public, authorities and other actors within a societal environment at a given time and place-is explored in the context of Communist and early post-Communist Russia (1917-1999). Three value pairs underlying the attitude towards information are explored: individualism and collectivism (the relation of man to the state), universalism and particularism (the relation of man to man), and pluralism versus dominance (the nature of knowledge and truth). Continuities are found between the Communist Soviet Union and post-Communist Russia in their instrumental use of media and information (collectivism), the view on information as a particular privilege rather than a universal right and the monopoly of truth. Post-Communism, therefore, appears not only as an indication of time (i.e. the period after Communism) but also as an indicator of the continuation of basic value orientations over these time periods.
\end{abstract}

\section{Keywords}

collectivism; Communism; information culture; particularism; post-Communism; Russia; value orientations

\section{Issue}

This article is part of the special issue "Turbulences of the Central and Eastern European Media", edited by Epp Lauk (University of Jyväskylä, Finland).

(C) 2015 by the author; licensee Cogitatio (Lisbon, Portugal). This article is licensed under a Creative Commons Attribution 4.0 International License (CC BY).

\section{Introduction}

International comparative research on media and journalism shifted attention, though not strictly consecutively in time, from normative press theories (e.g. Siebert, Peterson, \& Schramm, 1956) over media structures (e.g. Hallin \& Mancini, 2004) to journalism culture (e.g. Hanitzsch, 2011). Although the approach is different, they all touch the same ground: the interconnectedness between media and broader society. Media systems are not isolated systems: they differ according to the societies they are embedded in. This is in essence the most prominent thesis of the classical work Four Theories of the Press (Siebert et al., 1956, pp. 1-2): "The press always takes on the form and coloration of the social and political structures within which it operates. Especially, it reflects the system of social control whereby the relations of individuals and institutions are adjusted." Hallin and Mancini (2004, p. 8), in their turn, follow this thesis: "We shall follow the agenda set out by Siebert, Peterson, and Schramm in attempting to show how different media models are rooted in broader differences of political and economic structure." The variety in journalisms among countries also inspired the Worlds of Journalism project of Hanitzsch and colleagues. Professional milieus in journalism, defined by underlying value orientations, cut across national boundaries but are unevenly distributed among countries: "the nation still seems to be a primary reference for journalists and their practices" (Hanitzsch, 2011, p. 492).

In particular the interdependence between the media system and the political system seems beyond doubt. Political authorities naturally tend to use media as propaganda outlets and political instruments, but they are also able to install restrictions so as to restrain 
themselves and others from doing so. Politicians make media laws and shape media policy. Political models are the starting point for the majority of normative media theories and typologies. In reference to Four Theories of the Press, Hallin and Mancini (2004, p. 1) place their "primary focus on the relation between media systems and political systems". The Interdependence between the media system and the political system of one society is also empirically researched. Engesser and Franzetti (2011), for example, have done this on dimensions of freedom, diversity, centrality and tradition. The findings of Hanitzsch (2011, p. 492) in the context of journalism cultures "especially point to the significance of political forces that impose important limits on the professional autonomy of journalists."

The Communist system of the former Soviet Union is especially illustrative of the strong link between media and politics. Politics ceased to exist in the Soviet Union as a separate subsystem as everything became politicized. Media institutions were political institutions in the first place, and journalists were considered party workers. The ideology of Marxism-Leninism operated as the societal glue. Hence, the Soviet Union presented a clear, coherent, and distinct media model in line with its general political, economic, and ideological model. It was labelled the Communist model, the Soviet model, or the Marxist model. It was characterized by state (and party) ownership, centralization, partisan journalism, and (ideological) censorship (de Smaele, 2010).

As easy as labelling the Communist Soviet Union, as puzzling seems labelling post-Communist Russia. Consequently, both the media and the political (and societal) system are often described in terms of paradoxes (see for example Pasti \& Nordenstreng, 2013; de Smaele, 2006) and contrasts between theory and practice, between law and its implementation, between hearts and minds. An overview of classifications (de Smaele, 2010) shows labels that suggest a congruence with the democratic, Western model that is at best superficial and imperfect (democracy and market economy accompanied by epithets such as pseudo, illiberal, delegated or even authoritarian or totalitarian) and more indigenous Russian labels without even a reference to Western models such as elite corporatism (Shevtsova, 1996), etatism (Vartanova, 2006) or the authoritarian-corporate model (Zassoursky, 1999). One concept that has been particularly useful for the last twenty years and with a wider scope than Russia alone, is that of post-Communism.

The notion of post-Communism indicates the allpervasive influence and heritage of Communism. It is used to label the time period immediately following the Communist period. If something like a totalitarian syndrome exists - "a specific pattern of cognitions, attitudes and behaviours, developed in order to adapt to life under totalitarian circumstances" (Klicperová, Feierabend, \& Hofstetter, 1997, p. 39), it is only plausible that also a post-totalitarian syndrome plays its part. Several authors have pointed at the importance of mindsets and habits, routines, norms and values in determining the (often disappointing) pace of reforms: "It is not enough to introduce new institutions: what is also needed is the cultural foundations of those institutions, the values, attitudes and beliefs which make them work, and which encourage the people to take them for granted." (Jakubowicz, 2005, p.2)

Cultural foundations, values, attitudes and beliefs are at the centre of this study. The aim of this article is to look into the basic values underlying the attitude towards information in Russia during the transition from Communism to post-Communism, or from the Soviet Union (1917-1991) into the Russian Federation (1991-1999). A study on values evidently implies a longer time dimension as values do evolve albeit only slowly. The focus is on continuities between two historical periods that appear as separate in history books and timelines defined by the dissolution of the Soviet Union in 1991. At the same time, abrupt discontinuity is already tempered by the use of terms such as postCommunism, transition or transformation. Especially the Gorbachev years of glasnost and perestroika (1985-1991) are considered a crucial bridge period between Communism and post-Communism. Whereas both the era of Gorbachev (1985-1991) and Yeltsin (1991-1999) are included in this study, the Putin period (1999-today) is beyond its scope.

The article is structured as follows. First, we explain the concept of information culture in general terms. Three value pairs are singled out as underlying the information culture in a given society: individualismcollectivism, universalism-particularism, pluralismdominance. Secondly, we name the values prevalent in the former Soviet Union and compare them with the values dominant in Russia throughout the 1990s. The connection between values and society is not based upon one single survey but on a multitude of surveys, authors, testimonials and observations adding to the strength of the argument. By its method, the article can be considered a meta-analysis of divergent studies on Russian mass media scrutinized from the new angle of how information is produced and perceived within the society.

\section{The Concept of Information Culture}

In political science, the concept of political culture has taken hold strongly and is widely elaborated on. It has taught us that a certain political system (structure) isor must be-supported by a certain political culture as a set of attitudes, beliefs, values. Pioneering research on this topic was done by Gabriel Almond and Sidney Verba, in The Civic Culture (1963/1989). The idea, however, is not new. Plato already taught us that forms of government (oligarchy, democracy, aristocracy, tyran- 
ny) differ according to dispositions of men. In the Soviet Union, the concept of political culture was introduced by Burlatsky in the 1970s. White (1979, p. 58) traces the term policheskaya kul'tura back to Lenin and more recently to Brezhnev. But it is obviously in postCommunist Russia that the term is increasingly used (e.g. Sergeyev \& Biryukov, 1993).

The concept of political culture provides a link between the macro-structure (society) and the microstructure (individual): "Outcomes at the system level are thought to be determined by the interactions of individuals acting consistently in terms of the axioms of individual behaviour, whatever they may be. We make assumptions about individual consumers to understand markets, about voters to understand politics, and about bureaucrats to understand bureaucracies" (March \& Olsen, 1984, p. 736). Sergeyev and Biryukov (1993) base their study of the Russian parliament on the same principle. A parliament is not only an institution, operating according to certain rules and procedures, but also an organisation of "living minds": "The knowledge, habits, patterns of behaviour, ideas and social preconceptions of those who work in it have a profound impact on how it functions" (p. 7). All definitions of political culture encompass the following elements: attitudes (mainly attitudes towards authority), values, belief systems (ideological or pragmatic), a cognitive component (citizens' level of knowledge) and an affective component (identification with the political system, engagement or alienation). Political culture is part of the broader culture in an anthropological sense. Political values and orientations are intertwined with values and orientations in a broader sense (Brown, 1979 , p. 4, Deutsch, 1974, p. 237). Like other cultural concepts, the concept of political culture points to what is idiosyncratic in political and social systems.

Analogous concepts such as "academic culture" or "business culture" are increasingly being used. The concept of "information culture" is used predominantly in combination with information technology and digital media in the sense of coping with new information technologies. But also in the concept of "business culture" or "organisational culture", information plays a central role. It points at common orientations and practices within the organisation with regard to sharing, using, distributing information. Like political culture, information culture cannot be separated from culture as a whole but while political culture deals with orientations and attitudes towards authority and the distribution of authority, information culture deals with attitudes towards information and the distribution of information. Culture and communication are thus explicitly linked to each other. This is also the case in the view of Hall and Hall (1987), who define culture as primarily a system for creating, sending, storing and processing information. Informational culture, then, could be reduced to culture tout court.
Culture provides a link between present, past and future (its vertical dimension) and between different subsystems within society (its horizontal dimension). We consider the media system as an integral part of the broader societal system. The media system is a social system, encompassing media-institutions, media workers (such as journalists), the public, the politicians and news sources as well as the relations between all these actors, settled by laws, institutions and norms. McQuail (1994, p. 2) defines the media system as a "social institution, with its own distinctive set of norms and practices but with the scope of its activities subject to definition and limitation by the wider society". On the one hand, the media system operates according to intrinsic values and strives for autonomy; on the other hand, and at the same time, it is not an isolated system but it operates in close connection with the respective political, economic, and juridical systems as it is grounded in basically the same "culture". The concept of culture supposes a great deal of inertia and continuity-otherwise the term would not be able to exist (Wyman, 2000, p. 106). Triandis (1995, p. 4) has put the vertical dimension aptly: "Culture is to society, what memory is to individuals."

To summarize, we consider culture as a set of values, norms and beliefs that shape behaviour, as shared by a relatively large section of society (horizontal) and transmitted from one generation to another (vertical). In our further discussion, we limit ourselves to values as the most stable constituents of culture. The notion of "philosophy" used by Siebert et al. (1956) suggests a number of values: "one has to look at certain basic beliefs and assumptions which the society holds: the nature of man, the nature of society and the state, the relation of man to the state, and the nature of knowledge and truth" (p. 2). As the nature of man and society are most easily answered in relation to each other, the first three "questions" are reduced to two: the relation of man to the state is described by the values of individualism and collectivism, and the relation of man to man by the values of universalism and particularism. The nature of knowledge and truth is discussed with the help of the values pluralism and dominance.

\section{Values Underlying the Information Culture in Russia}

\subsection{Relation of Man to the State: Collectivism versus Individualism}

The values of individualism and collectivism express the two basic positions with regard to the relation of man to the state. In an individualistic theory, the individual is a rational being and an end in itself, whose happiness and well-being is the goal of society. In the collectivistic theory, the individual is, above all, a part of society, and not an end in itself. The group takes on 
a greater importance, since only through the group may an individual accomplish his/her purposes (Siebert et al., 1956, p. 11). Individualism and collectivism are considered as values at the level of the community or society, not at the individual level. They cannot be equalized to egoism and altruism. Collectivism is not altruism but "in-group egoism" (Hofstede, 1994, p. xiii). Some authors use different terms to distinguish between the cultural and personal levels. Triandis (1995), for example, uses "idiocentrism" and "allocentrism" on the individual level in contrast to collectivism and individualism on the societal level. Berry (1994) uses individualism and collectivism for both levels but in combination with "societal" or "personal". Kagitçibasi (1994) replaces individualism and collectivism by "cultures of relatedness" and "cultures of separateness" to avoid the negative connotation of collectivism with group pressure and mass behaviour. Individualism is commonly associated with liberalism: the focus is on the individual, on individual rights, initiative, and individual freedom. In an individualist society, the individual right to information ("right to know") prevails and media are expected to act accordingly. In a collectivist society, the general interest prevails over the individual right to information and the media primarily act as instruments of the authorities.

As for the Soviet Union, few dispute the collectivist nature of society expressed "by placing social (state, Party, group) loyalties above individual rights" (Kon, 1996, p. 188). Art. 39 of the 1977 Constitution guaranteed the Soviet citizens social, economic, political, and personal rights and freedoms, but also stipulated that citizens' rights might not be exercised at the expense of the interests of society or the state. Individual rights and freedoms (e.g. Art. 50: freedom of speech and the press) were awarded "in accordance with the interests of the people and in order to strengthen and develop the socialist system". In Western liberalism, "state" (government, president, army, security services) (gosudarstvo) is considered as the antipode of "society" (civil society) (obshchestvo). In the official Soviet discourse, however, state and society were as one, placed opposite the individual. Igor Kon (1996, p. 190) points out that neither the Soviet Philosophical Encyclopedia of the 1960s nor the six successive editions of the Ethical Dictionary, published between 1965 and 1989 , had an entry on "personal" or "private" life. Private life was only briefly touched upon, accompanied by the remark that it was not allowed to hinder public life. Both strict child-rearing practices in families and at school and an oppressive atmosphere at work fostered conformity: “The attempted 'over-socialization' into groups (collectives) suppressed the individuality of the individual" (Klicperová et al., 1997, p. 40).

In his classification of collectivistic and individualistic countries, Triandis (1995, p. 3) also places Russia in the 1990s, like the Soviet Union, among the collec- tivistic countries. Notwithstanding the changing official discourse of the early 1990s (e.g. the Constitution of 1993 with its stress on individual rights and freedoms), the supremacy of the state is kept nearly untouched by all reforms. Vladimir Putin's "millennium speech" (1999) with its stress on traditional Russian valuessuch as patriotism (pride in Russia, its history and accomplishments), derzhavnost' (belief in a Great Russia), gosudarstvennichestvo (etatism or 'the state as source and protector of order and as driving force of change') and sotsial'naya solidarnost' (social solidarity)-is a textbook example of the preference of collectivism over individualism.

A different appreciation of the individual by individualistic and collectivistic societies evidently affects the attitude towards information and the media as information carriers. The rational individual has an individual and universal right to freely available information through autonomous media. The "cog in the wheel" (Heller, 1988) receives its particular part of the information, modelled according to societal goals, through dependent and instrumental media. The lack of autonomy, and consequently the instrumentality of mass media, is an element of continuity in Russian history. Its social subsystems of politics, economics, law and media have never been clearly distinguished from each other. In tsarist Russia, the tsar represented legal, executive, and juridical power (Malfliet, 1999, p. 36) and was often personally engaged in information matters (e.g. Peter the Great, Catharina the Great). In the Soviet Union, the Communist Party took over these tasks. The political, economic, juridical and media systems were closely integrated and connected by ideology (Marxism-Leninism) and the Party organization. The mass media were considered instruments of the vanguard Party. Lenin formulated the task of the mass media as a collectivist propagandist, agitator and organizer (Bol'shaya, 1952, vol. 10, p. 8). Journalists were party functionaries in the first place, but of a type that could also write (Lenin, 1988, pp. 66-67). Stalin not only used the term "instrument" (orudie) but also the word "weapon" (oruzhie) to describe mass media (Bol'shaya, 1952, vol. 10, p. 8). The most important principle, as listed in handbooks for journalists, was "partiality" or partiinost' (de Smaele, 2001, pp. 38-42). Information was made instrumental to societal goals.

The instrumental view of mass media survived Communism. Mikhaïl Gorbachev (1985-1991) depended on the mass media to promote his glasnost policy and to win the population for his reforms. The media function of mobilization was kept untouched, only its goal changed slightly into dynamic socialism instead of stagnant Communism. Boris Yeltsin (1991-1999) was the self-appointed patron of press freedom, but in return he, too, expected loyal support for his reforms from the media. Newspapers that were favourably disposed towards Yeltsin's regime, were financially re- 
warded (Richter, 1995, pp. 15-16). In the run-up to the presidential elections of June 1996, the mass media were massively mobilized to secure Yeltsin's second term as president (EIM, 1996). Moscow students of journalism throughout the 1990s were taught the lasting value of partiinost' (Prokhorov, 1998, pp. 157-88) and the educational, ideological and organisational rather than the informational functions of the mass media (Prokhorov, 1998, pp. 46-48). The difference between Yeltsin's Russia and the Soviet Union was that not all journalists were instruments for one and the same government or party. Instead, they were at the disposal of widely divergent patrons. Hence, Yeltsin's Russia evolved into a corporate or oligarchic system with him as arbitrator among concurrent power groups of politicians, bankers, media tycoons, business people and bureaucrats. Due to the strong political-economic conflict of interest of the elite, the autonomy of the social subsystems, including the media system, remained limited. Media magnates were simultaneously politicians and businessmen. Their investments in the media were inspired by both economic gain and political ambitions (Vartanova, 1997). Analogous to the corporate societal system, Yassen Zassoursky (1999) labelled the Russian media system in the late 1990s an "authoritarian-corporate system". His grandson, Ivan Zassoursky (1999), spoke of the "mediapolitical system". Both labels point to the symbiosis of private capital, politics and media. The latter are not an independent "fourth power", but serve the (political-economic) power groups.

The individual and collective interests are conflicting values everywhere. But, whereas in WesternEurope the basic right is the individual right to information, and limitations to that freedom are the exceptions, the opposite is true of transitional Russia. Mikhail Gulyaev (1996, p. 14) speaks about "the tradition of the policy of enforced secrecy" as a method to control the information flow. Notwithstanding the law, restricted access to information is common practice. Participants of an IREX meeting (IREX, 2001, p. 196) to discuss the media situation in Russia came to the conclusion that "access to some publicly relevant information is not free: authorities continue to view information as their property, and want to control access." In the annual reports of violations of journalists' rights (compiled by the Glasnost Defence Foundation since 1993), the violation of their right to informationnamely denials of information, refusals of accreditation and admission to press conferences and certain locations-remains a highly quoted problem. Surveys cited by Svitich and Shiryaeva (1997, p. 157) confirm this finding as well as the deterioration of the situation throughout the 1990s. Especially difficult to obtain are bare facts, figures, and documents. Little has changed in this respect since Soviet times. The executive branch has the worst reputation with regard to openness of information, followed by the security services, commer- cial, state and financial companies. Since the Soviet era, state organisations have generally become less transparent with less clearly defined functions and competences (Svitich \& Shiryaeva, 1997, pp. 154-160). Not only the state is to blame. Whereas American journalists consider the watchdog role of journalists vis à vis the government their second most important task (following the distribution of information), Russian journalists do not as "they share leadership with state officials" (Wu, Weaver, \& Johnson, 1996, p. 538). According to the same survey, Russian journalists stress their role in shaping the political agenda twelve times more than American journalists, a role the latter in fact consider of least importance.

\subsection{Relation of Man to Man: Particularism versus Universalism}

When the relation of man to the state is expressed by the value pair individualism and collectivism, the relation of man to man can be described by the values of universalism versus particularism. In short and in general, the distinction comes down to the precedence of general rules, codes, values and standards over particular needs and claims of friends and relations (universalism) or, in contrast, the precedence of human friendship, relations, and situations over rules (particularism). In the original, theological sense, universalism points to the belief that ultimately all humanity will be saved by God's grace. Particularism, on the other hand, holds that only the chosen will be saved. In the sociological sense, the pair universalism-particularism derives first and foremost from the dichotomic pattern-variables of Talcott Parsons (1990). These are patterns of inherently cultural value-orientation, but they become integrated both in personalities and in societal systems. The choice between universalism and particularism comes down to the choice between a cognitive or an appreciative standard, between referring to a general framework (objectivity) or itself (subjectivity). In the ontological or philosophical-anthropological sense, as underlying the French Revolution and the Enlightenment, universalism sees all men as equal. Universalism then is "the treatment of all persons alike based upon general criteria and not upon any special or unique characteristics of the persons themselves" (Orum, Johnstone, \& Riger, 1999, p. 534) whereas particularism is "the treatment of people as special individuals, based on their personal features, rather than as members of some broader class or group" (Orum et al., 1999, p. 528). The distinction between universalism and particularism reminds us of Tönnies's distinction between Gesellschaft and Gemeinschaft or Durkheim's distinction between "mechanical" and "organic" solidarity. Universalism, Gesellschaft or organic solidarity is commonly associated with liberalism, civil society and rationalism. Particularism, Gemeinschaft or me- 
chanic solidarity is associated with nationalism and romanticism (e.g. Mertus, 1999).

Particularistic cultures are-in the terminology of Edward T. Hall (1976/1989)-high context communication environments while universalist cultures are low context communication environments. Context, in this sense, has to do with how much you need to know before you can communicate effectively. In high-context cultures "most of the information is either in the physical context or internalized in the person, while very little is in the coded, explicit, transmitted part of the message". In low-context cultures, in contrast, "the mass of information is vested in the explicit code" (Hall, 1989, p. 91). Consequently, high-context cultures communicate intensively within their in-groups that are aware of the context while out-groups are largely left out (particularism). Low-context cultures do not differentiate as much as high-context cultures between in- and out-groups; information is freely available for both in- and out-group members (universalism). More specifically, we can state that information is considered a universal right-for all individuals without distinction-in the universalistic variant and a particularistic right or a privilege-for certain groups or individualsin the particularistic variant.

Despite its theoretical "universal" ambitions, Communist Russia was particularistic rather than universalistic: "Important features of the Leninist type were that it was not based on citizenship and that it was not, despite its protestations, universalistic in the real sense of the word, because entitlement to social benefits depended upon being a loyal worker or employee of the state", Mareš, Musil and Rabušic (1994, p. 83) write. The sociologist Igor Kon (1996, p. 197) points at the priority of the "particularistic norm of group privilege over the universalistic principle of human rights". The Orwellian phrase "all animals are equal but some animals are more equal than others" reveals as nothing else the discrepancy between the universalist claims and the particularist reality. The empirical study based on the World Values Survey of 1991 reveals for early postCommunist Russia a weak score on the value of "universalism" and confirms the failed universal ambition of Marxism in Russia (Verbeeren \& de Smaele, 2004).

Information in Russia has never been available to everyone on the same conditions. In sharp contrast with the theoretical ideal of the classless society, Soviet society was characterized by a strong vertical segregation with the "elite" (party leaders) on the one hand and "the mass" on the other. Novosel (1995) speaks of "first class" and "second class" citizens. The first was a privileged class whose privileges were institutionalised by the nomenklatura system. These not only encompassed material privileges (such as housing, food, health care, and education) but also enhanced access to information, from the right to see "forbidden" films or read "forbidden" books (that is, films and books not considered suitable for general distribution) (e.g. Benn, 1992, p. 9) to the receipt of special foreign news bulletins, put together on a daily basis by TASS and distributed on differently coloured paper according to the degree of detail and the targeted readers (Lendvai, 1981, pp. 129-131). Although the highly-placed officials obviously could claim access to more information, they too received information on a "need-to-know" basis (Bauer, Inkeles, \& Kluchkhohn, 1959, p. 43). The overall result was an information deficit. Information was one of the most sought after commodities in the Soviet Union (Ellis, 1999, p. 6). Informal networks, oral communication and rumours filled the vacuum (Banai, 1997, p. 252; Bauer \& Gleicher, 1964; Chilton, Ilyin, \& Mey, 1998 , p. 20; Inkeles \& Bauer, 1959, pp. 163-165). Parallel to the official information circuit and analogous to the black market, an unofficial information circuit (e.g. samizdat) was functioning. Bauer et al. (1959, pp. 7478) speak of "informal adjustive mechanisms" developed by the population as a reaction to the high degree of control and centralization. The use of personal networks and informal contacts to obtain sparsely available goods, services, and information and to sidestep formal procedures, is indicated by the Russian word blat or the term ZIS (znakomstva I svyazi, acquaintances and contacts) (Ledeneva, 1998, p. 1). These informal blat-networks can be considered particularistic networks wherein personal ties do play a bigger part than universal procedures and institutions: "It was in essence a value-system that depended upon men and not upon laws" (Markham, 1967, p. 21). Ellis (1999, pp. 6-7) speaks about a paradox: the Soviet Union honours the principle of "public property" but refuses to consider information as a public property whereas in the West private property and owners' rights are honoured but much information is freely accessible to everyone.

The particularist orientation can be found in all aspects of societal organization. Russian political life, for example, is highly characterized by particular in-groups versus out-groups: different clans or oligarchs fight each other and value their particular interests higher than the common interest. In economics, personal, particularistic relations, often linked with corruption and privileges, are more important than professional, impersonal, universal market relations, procedures and institutions (Bryant, 1994, p. 70). In the transition from Communism to post-Communism, privileged access to information played a crucial role in the process of privatizations, which became known as insider privatizations (e.g. Arik, 1999, pp. 52-53). State property was privatized according to rules written by "the elite" for itself (Androunas, 1993, p. 45). Together with Ledeneva (1998, pp. 184-185) we can state that blat played a role in the first privatizations. Whereas in the Soviet Union information concerned mainly what, where and how to obtain scarce goods, during the transition period it also 
pertained to information about money, business, laws and taxes, licenses, loans and other scarce 'inside' information (Ledeneva, 1998, p. 209).

Privileged information played an important role in the transition process, but remains important also in post-Communist Russia, where the right to information and inadmissibility of censorship are included in the 1993 Constitution (Art. 29) and in the 1991 Russian Federation Law on the Mass Media (Art. 1). Notwithstanding the law, access to information remains a much quoted problem. The sole remedy according to Konovalov (2002, p. 49) lies in maintaining close and personal connections with, for example, the Defence Ministry and the security services. The observation of Vladimir Ermolin (2002, p. 7) is identical: journalists do not receive rights by laws, but by the personal preference of (state) officials and press services. By law, the media are equal, but by preference some are more equal than others. Code words in the process of information gathering in Russia remain "trust, relations, and integration" (Banai, 1997, p. 242). Authorities have relations with some media professionals, who enjoy the privilege to receive information unavailable to the rest of the media. Among the privileged media in the Yeltsin era were, according to Gulyaev (1996, p. 14), news agencies such as ITAR-TASS and Interfaks, newspapers such as Kommersant and Izvestiya, and weeklies such as Argumenti i Fakty. The most important private channel NTV has had changing relationships with the president and his administration (from "neutral" or "opposition" in 1994-1995 to "supporter" during the 1996 presidential elections, and "opposition" in 2000). With each phase the level of access to information shifted accordingly. In the early years, when NTV adopted an oppositional stand, access to the Kremlin was forbidden for NTV-journalists on occasions. In September 1996, however, the "collaborating" channel received a broadcast license for the entire fourth channel by presidential decree and enjoyed privileges such as the same transmission rates as state channels and enhanced access to information. Acting in opposition again, the channel saw its privileges, and ultimately its future, disappear. Another illustration is provided by the Kremlin's handling of the Kursk disaster in the summer of 2000. Media coverage was restricted, only one journalist from the state-controlled television channel RTR was granted full access to the scene. Konovalov (2002, p. 51) calls the Kursk disaster crucial for dividing journalists into "ours" and "others". Journalists of state media like RTR are "ours" and consequently enjoy enhanced access to information. Konovalov also ranks the obedient media according to their proximity to the Kremlin (for television stations, in declining order: RTR, ORT, NTV, TV-Centre).

Very few journalists or media claim their right to receive information before court (Svitich \& Shiryaeva, 1997, p. 160). They prefer to overcome the information barriers by other means, such as maintaining privileged relations or bribing officials and openly purchasing information from them. Journalists also only rarely send formal letters of inquiry. Formal inquiry, moreover, appears as a highly ineffective method in comparison with personal contacts and visits to institutions and officials. An experimental study in Voronezh is illustrative: where approximately $70 \%$ of formal letters of enquiry resulted in the refusal of information, $70 \%$ of personal visits to officials, in contrast, led to acceptance and access to information (Arapova, 2003). And, "if these methods ['back doors', privileged relations, personal contacts] are beyond them, they [the journalists] resort to fabrication and conjecture" according to the Presidential Judicial Chamber for Information Disputes and the Union of Russian Journalists in their 1995 "joint recommendation on the freedom of mass information and the responsibility of journalists" (Price, Richter, \& Yu, 2002, p. 341). The latter, thus, assigns responsibility for the dissemination of untruthful information in the media to the closed administration: "Unreliability, incompleteness, and distortion of information very often results from the inaccessibility of sources of information" (Price et al., 2002, p. 341).

\subsection{Nature of Knowledge and Truth: Dominance versus Pluralism}

Pluralism, commonly associated with democracy and liberalism, acknowledges the existence of all (political) players and their opinions. Consequently, in a pluralist democracy one does not seek the one and only truth but a workable compromise, a balanced view acceptable to all. The pluralist "search for truth" contrasts with the dominant "monopoly of truth". In an authoritarian society, "truth was conceived to be not the product of the great mass of people, but of a few wise men who were in a position to guide and direct their fellows. Thus truth was thought to be centered near the center of power." (Siebert et al., 1956, p. 2).

Authoritarian societies are closed societies: "societies that do not accept the legitimacy of different perspectives on social, political, religious, or normative questions on which reasonable men inevitably disagree" (Mayer, 1989, p. 236). Open, pluralist societies, in contrast, welcome divergent views. In order to reveal the truth, all opinions need to be heard in an open marketplace: "pluralistic views of reality, taken together, were expected to provide a representative mosaic of truth" (Schoenbach, 1983, p. 34). A closed, dominant society rejects freedom of information as useless or disturbing while an open, pluralist society considers freedom of information as essential to its health.

The Soviet Union was a closed society: closed for information from outside (e.g. jamming of foreign radio stations, limited import of foreign books and journals, small percentage of foreign television programmes) 
but also reluctant to release "inside information" to its own citizens. Journalists (who were carefully selected and educated) had extremely limited access to information in the first place, and even the information acquired had to pass several strict (mainly politicalideological) filters before appearing in the news. A limited flow of information was the norm.

As in Communist Russia (see for example Berdjajew, 1947, p. 5), in post-Communist Russia too the monopolistic view on truth and a dualist view on morality (good versus bad) are twin leading principles. Politics and morals are often confused, various opinions are not considered to be morally equal (Dolgopolov, 2000, p. 5; McDaniel, 1996, p. 17). What is strived for in Russia, is not "a" decision but "the" -right-decision (Sergeyev \& Biryukov, 1993, p. 25). "Truth is unitary...community must also be unitary...opposition and diversity is falsehood and therefore deserves no hearing", McDaniel (1936, p. 35) summarizes. Levada (1996, p. 300) and Millard (1994, p. 27), in their turn, point at intolerance towards dissident or divergent behaviour. William Zimmerman (1995, p. 631) has called this "synoptic thinking": "the view that there is only one correct philosophy". The Russian word sobornost' not only points at the (mystic) unity and connectedness of the Russian people but has also a political connotation, with the meaning of a dislike of fractions and opposition and a preference for unanimous decisions. Sergeyev and Biryukov (1993) contrast the "model of sobornost" with the parliamentarian model with its fractions, representations and compromise. McDaniel (1996, p. 52) places the Russian "government of truth" versus the Western "government of law".

\subsection{Clusters of Values}

The above-mentioned values form coherent clusters. The values of universalism, individualism and pluralism seem to gather, and so do the values of collectivism, particularism and dominance. Hofstede (1994, p. 2), for example, found a strong correlation between individualism, universalism, and autonomy on the one hand, and collectivism, particularism, and dependency on the other. Triandis (1995, p. 19) connects individualism with liberalism and collectivism with authoritarianism and Marxist collectivism. More in general he links the former with 'the West' and the latter with "the rest" (Triandis, 1995, p. 13). More recent empirical research on universalism based on the World Values Survey showed a clear North-South and East-West opposition within Europe, and a correlation between universalism and democracy (Verbeeren \& de Smaele, 2004). Suvarierol (2004) studied the communication habits of European Commission officials and observed a clear North-South dimension according to the degree of universalism causing different communication behaviour patterns. In general, a parallel between universalism and transparency of governance-interpreted as openness of government information-can be observed. The Nordic countries, which score high on universalism, are forerunners in the domain of transparency of governance too. Sweden, together with Finland, were the first in Europe to install in 1766 the "Act on the Freedom of Publishing and the Right of Access to Official Documents" (Janssen, 2012). Both were followed by the other Nordic countries Norway and Denmark, as well as "universalist" France and The Netherlands. Transparency of governance in Central and Southern European countries was the subject of legislative acts only much later, and in fact, legislation still is inadequately implemented (Suvarierol, 2004).

The majority of media systems can be situated somewhere in between the two extremes of pluralism and dominance. Hence, the classification is not to be considered a strict dichotomy but a continuum going from full autonomy to complete control. The distinctive criterion, thus, is the degree of control. Additionally, also the perception and appreciation of control plays a role. Whereas in the West, control over media is perceived negatively and media autonomy is seen as an ideal (but not necessarily within reach), in the Soviet Union, for example, personal and media autonomy were consciously rejected. Sparks $(2000$, p. 36) formulated this as follows: "the only real difference between what was believed in Prospect Marxa 20 [Lenin's view on the press] and what was believed in the Armory Building [Schramm's description of the Communist press in Four Theories] was in the evaluation of the system in question". The same could be said for the majority of non-Western countries that do not necessarily appreciate the Western ideal of freedom or, indeed, so-called "chaos" (Merrill, 2002, pp. 22-23).

\section{Conclusion}

We looked into the concept of information culture during transition from Communism to post-Communism in Russia. Collectivism, particularism and dominance appear as key values to describe the handling of information in both the Communist Soviet Union and postCommunist Russia in the 1990s. In this article we did not go into the many changes in Russian media during transition. Changes, though, are numerous. PostCommunist Russia became a different country with regard to media ownership structure, media law, and media content. The 1993 Constitution fundamentally reversed the relation of man to the state and acknowledged the principles of individuality, plurality, democracy, and market economy. De jure this is an obvious "out of the old" and "into the new". The de facto implementation of the law and everyday behaviour, however, could raise doubt about the consolidation of the new order and reminds us of the earlier cited quote of Karol Jakubowicz (2005, p. 2): "It is not enough to in- 
troduce new institutions: what is also needed is the cultural foundations of those institutions, the values, attitudes and beliefs which make them work, and which encourage the people to take them for granted."

Western observers and advisers perhaps too easily presumed that "the new order" automatically would be "the Western order". The overview of the first ten years of post-Communist Russia reveal that at least in the field of information and communication dominant values were not all of a sudden replaced by Western values. A further look into the Putin era is recommendable to extend the time dimension of the study and to see whether values start to modify or consolidate. As for Yeltsin's Russia, we can conclude that it is postCommunist indeed, by continued value orientations prevalent also in Communist Russia.

\section{Acknowledgments}

The research was partially supported by the Brussels Center for Journalism Studies.

\section{Conflict of Interests}

The author declares no conflict of interests.

\section{References}

Almond, G. A., \& Verba, S. (1963/1989). The civic culture. Political attitudes and democracy in five nations. London: Sage.

Androunas, E. (1993). Soviet media in transition. Structural and economic alternatives. Londen: Praeger.

Arapova, G. (2003). The right to access to information: Monitoring experience. Media Expert, 4. Retrieved from http://www.medialaw.ru/e_pages/laws/project/ r2-3.htm

Arik, M. (1999). Controversies of the post-Communist transition. Eurasian Studies, 16(autumn-winter), 5173.

Banai, M. (1997). Children of the system: Management in Russia. In T. Clark (Ed.), Advancement in organizational behaviour. Essays in honour of Derek S. Pugh (pp. 241-257). Aldershot, Brookfield: Ashgate.

Bauer, R. A., Inkeles, A., \& Kluchkhohn, C. (1959). How the Soviet system works. Cultural, psychological, and social themes. Cambridge: Harvard University Press.

Bauer, R. A., \& Gleicher, D. B. (1964). Word-of-mouth communication in the Soviet Union. In L. A. Dexter \& D. M. White (Eds.), People, society and mass communications (pp. 413-428). New York: The Free Press of Glencoe.

Benn, D. W. (1992). From glasnost to freedom of speech. Russian openness and international relations. London: Pinter.

Berdjajew, N. (1947). Het Russische denken in de $19^{e}$ \& $20^{e}$ eeuw. Aspecten en perspectieven (oorspr.
Russkaya mysl' v devyatnadsatom veke $i$ v nachale dvadsatogo veka). Amsterdam: De Bezige Bij.

Berry, J. W. (1994). Ecology of individualism and collectivism. In U. Kim, H. C. Triandis, Ç. Kâgitçibasi, S.-C. Choi, \& G. Yoon (Eds.), Individualism and collectivism. Theory, method, and applications (pp. 77-84). London: Sage.

Bol'shaya (1952). Bol'shaya Sovetskaya Entsiklopediya $\left(2^{\text {nd }}\right.$ ed., Vol. 10). Moscow: Gosudarstvennoe Nauchnoe Izdatel'stvo.

Brown, A. (1979). Introduction. In A. Brown \& J. Gray (Eds.), Political culture and political change in Communist states (2nd ed., pp. 1-24). London: MacMillan.

Bryant, C. (1994). Economic utopianism and sociological realism. Strategies for transformation in East-Central Europe. In C. Bryant \& E. Mokrzycki (Eds.), The new great transformation? Change and continuity in EastCentral Europe. London: Routledge.

Chilton, P. A., Ilyin, M. V., \& Mey, J. L. (Eds.) (1998). Political discourse in transition in Europe 1989-1991. Amsterdam: Benjamin Publishing Company.

de Smaele, H. (2001). Massamedia in Communistisch en postCommunistisch Rusland (1917-2000). Factoren van continuïteit of van verandering? (doctoral dissertation). Gent: Universiteit Gent.

de Smaele, H. (2006). In the name of democracy: The paradox of democracy and press freedom in postCommunist Russia. In K. Voltmer (Ed.), Mass media and political communication in new democracies (pp. 42-58). London: Routledge.

de Smaele, H. (2010). In search of a label for the Russian media system. In B. Dobek-Ostrowska, M. Glowacki, K. Jakubowicz, \& M. Sükösd (Eds.), Comparative media systems: European and global perspectives (pp. 41-62). Budapest: CEU Press.

Deutsch, K.W. (1974) Politics and government. How people decide their fate (2nd ed.). Boston: Houghton Mifflin Company.

Dolgopolov, G. (2000). World history in 60 seconds: How Bank Imperial re-edited Russian binary logic. Social Semiotics, 10(1), 5-20.

EIM (European Institute for the Media). (1996). Preliminary Report. Media and the Russian presidential elections, 4 July 1996. Düsseldorf: European Institute for the Media.

Ellis, F. (1999). From glasnost to the Internet. Russia's new infosphere. London: Macmillan.

Engesser, S., \& Franzetti, A. (2011). Media systems and political systems: Dimensions of comparison. International Communication Gazette, 73(4), 273-301.

Ermolin, V. (2002). Pressa i silovye vedomstva: vzaimoterpimost' kak forma sotrudnichestva. In M. Pogorelyj \& I. Safranchuk (Eds), Sovremennaya rossijskaya voennaya zhurnalistika. Opyt, problemy, perspektivy (pp. 73-86). Moscow: Gendal'f.

Gulyaev, M. (1996). Media as contested power in post- 
glasnost Russia. Post-Soviet Media Law \& Policy Newsletter, 29, 12-16.

Hall, E. T. (1976/1989). Beyond culture. New York: Doubleday.

Hall, E. T., \& Hall, M. R. (1987). Hidden differences. Doing business with the Japanese. Garden City, NY: Anchor Press/Doubleday.

Hallin, D. C., \& Mancini, P. (2004). Comparing media systems. Three models of media and politics. Cambridge: Cambridge University Press.

Hallin, D. C., \& Mancini, P. (2012). Comparing media systems beyond the Western world. Cambridge: Cambridge University Press.

Hanitzsch, T. (2011). Populist disseminators, detached watchdogs, critical change agents and opportunist facilitators: professional milieus, the journalistic field and autonomy in 18 countries. International Communication Gazette, 73(6), 477-494.

Heller, M. (1988). Cogs in the wheel. The formation of Soviet man. New York: Alfred A. Knopf.

Hofstede, G. (1994). Foreword. In U. Kim, H. C. Triandis, Ç. Kâgitçibasi, S.-C. Choi, \& G. Yoon (Eds.), Individualism and collectivism. Theory, method, and applications (pp. ix-xiii). Thousand Oaks, London, New Delhi: Sage.

Inkeles, A., \& Bauer, R. A. (1959). The Soviet citizen. Daily life in a totalitarian society. Cambridge: Harvard University Press.

IREX (International Research \& Exchange Board). (2001). Media Sustainability Index 2001. Retrieved from http://www.irex.org/msi/index.asp

Jakubowicz, K. (2005, March). Post-Communist media development in perspective. In Internationale Politikanalyse: Europäische Politik/Politikinformation Osteuropa. Bonn: Friedrich Ebert Stiftung.

Janssen, K. (2012). Open government data and the right to information: opportunities and obstacles. The Journal of Community Informatics, 8(2). Retrieved from http://www.ci-journal.net/index.php/ciej/arti cle/view/952/954

Kagitçibasi, Ç. (1994). A critical appraisal of individualism and collectivism. Toward a new formulation. In $\mathrm{U}$. Kim, H. C. Triandis, Ç. Kâgitçibasi, S.-C. Choi, \& G. Yoon (Eds.), Individualism and collectivism. Theory, method, and applications (pp. 52-65). Thousand Oaks, London, New Delhi: Sage.

Klicperová, M., Feierabend, I. K., \& Hofstetter, R. (1997). In the search for a post-Communist syndrome: A theoretical framework and empirical assessment. Journal of Community \& Applied Social Psychology, 7, 39-52.

Kon, I. S. (1996). Moral culture. In D. Shalin (Ed.), Russian culture at the crossroads. Paradoxes of postCommunist consciousness (pp. 185-207). Boulder, CO: Westview Press.

Konovalov, I. (2002). Voennaya telezhurnalistika: osobennosti zhanra. In M. Pogorelyi, \& I. Safranchuk
(Eds.), Sovremennaya rossiiskaya voennaya zhurnalistika. Opyt, problemy, perspektivy (pp. 40-59). Moscow: Gendal'f.

Ledeneva, A. V. (1998). Russia's economy of favours: Blat, networking, and informal exchange. Cambridge: Cambridge University Press.

Lendvai, P. (1981). The bureaucracy of truth. How Communist governments manage the news. London: Burnett Books.

Lenin, V. I. (1988). Over kunst en literatuur. Moscow: Progres.

Levada, Y. A. (1996). Civic culture. In D. Shalin (Ed.), Russian culture at the crossroads. Paradoxes of postCommunist consciousness (pp. 299-319). Boulder, CO: Westview Press.

Malfliet, K. (1999). De geest van het Russische recht. Een voorstudie. Leuven and Amersfoort: Acco.

March, J. G., \& Olsen, J. P. (1984). The new institutionalism: organizational factors in political life. American Political Science Review, 78(3), 734-749.

Mareš, P., Musil, L., \& Rabušic, L. (1994). Values and the welfare state in Czechoslovakia. In C. Bryant \& E. Mokrzycki (Eds.), The new great transformation? Change and continuity in East-Central Europe (pp. 78-98). London: Routledge.

Markham, J. W. (1967). Voices of the red giants. Communications in Russia and China. Ames: The lowa State University Press.

Mayer, L. C. (1989). Redefining comparative politics. Promise versus performance. London: Sage.

McDaniel, T. (1996). The agony of the Russian idea. Princeton, NJ: Princeton University Press.

McQuail, D. (1994). Mass communication theory: An introduction (3th ed.). London: Sage.

Merrill, J.C. (2002). Chaos and order. Sacrificing the individual for the sake of social harmony. In J. B. Atkins (Ed.), The mission: Journalism, ethics and the world (pp. 17-35). Ames: lowa State Press.

Mertus, J. (1999). The liberal state vs the national soul: Mapping civil society transplants. Social and Legal Studies, 8(1), 121-146.

Millard, F. (1994). The anatomy of the new Poland. PostCommunist politics in its first phase. Aldershot: Edward Elgar.

Novosel, P. (1995). The iron law of communication. In D. J. Paletz, K. Jakubowicz, \& P. Novosel (Eds.), Glasnost and after. Media and change in Central and Eastern Europe (pp. 9-17). Cresskill, NJ: Hampton Press.

Orum, A. M., Johnstone, J. W. C., \& Riger, S. (1999). Changing societies. Essential sociology for our times. Lanham, Boulder, New York and Oxford: Rowman \& Littlefield Publishers.

Parsons, T. (1990). Towards a general theory of action. Michigan: UMI.

Pasti, S., \& Nordenstreng, K. (2013). Paradoxes of journalistic profession: Case of Russia in the context of the Brics countries. In E. L. Vartanova (Ed.), World of 
media: Yearbook of Russian media and journalism studies (pp. 243-268). Moscow: Lomonosov Moscow State University.

Price, M. E., Richter, A., \& Yu, P. K. (Eds.) (2002). Russian media law and policy in the Yeltsin decade. Essays and documents. The Hague, London and New York: Kluwer Law International.

Prokhorov, E. P. (1998). Vvedenie v teoriy zhurnalistiki. Uchebnoe posobie ( $2^{\text {nd }}$ ed.). Moscow: RIP-kholding.

Putin, V. (1999, 31 December). Rossiya na rubezhe tysyacheleti. Retrieved from http://www.government. gov.ru/government/minister/article-vvpl.html

Richter, A. (1995). The Russian press after Perestroika. Canadian Journal of Communication, 20(1), 7-23.

Schoenbach, K. (1983). News in the Western world. In J. L. Martin \& A. G. Chaudhary (Eds.), Comparative mass media systems (pp. 33-43). New York: Longman.

Sergeyev, V., \& Biryukov, N. (1993). Russia's road to democracy. Parliament, Communism and traditional culture. Aldershot \& Brookfield: Edward Elgar.

Shevtsova, L. (1996). After the elections: The balance of power among political institutions. Paper presented at the Conference "Five Years into the Transition: where is Russia headed?", Washington, DC, National Endowment for Democracy and Carnegie Endowment for International Peace, 20 September.

Siebert, F. S., Peterson, T., \& Schramm, W. (1956). Four theories of the press. The authoritarian, libertarian, social responsibility and Soviet Communist concepts of what the press should be and do. Urbana: University of Illinois Press.

Sparks, C. (2000). Media theory after the fall of European Communism. Why the old models from East and West won't do any more. In J. Curran \& M.-J. Park (Eds.), De-Westernizing media studies (pp. 35-49). London: Routledge.

Suvarierol, S. (2004). Evolving culture in the European Commission? Commission officials, cultural differences, and networking behavior. Research outline for the NIG annual work conference. Retrieved from https://ep.eur.nl/bitstream/1765/1745/2/NIG1-06.p df\#search=\%22suvarierol\%20EC\%20universalism\%22
Svitich, L. G., \& Shiryaeva, A. A. (1997). Zhurnalistskoe obrazovanie: vzglyad sotsiologa. Moscow: IKAR.

Triandis, H. C. (1995). Individualism \& collectivism. Boulder, San Francisco and Oxford: Westview Press.

Vartanova, E. (1997). Russian financial elite as media moguls. Paper presented at the International Conference on Media and Politics, 27 February-1 March 1997. Brussels: KUB.

Vartanova, E. (2006, 15 November). Russian media between the West and the East. Lecture. Helsinki: Aleksanteri Institute. Retrieved from http://www. helsinki.fi/aleksanteri/maisterikoulu/opintoopas/luentokurssit/oppimateriaali/russian_media_m odel/Lecture_2.ppt\#256,1,Russia Media between the West and the East

Verbeeren, J., \& de Smaele, H. (2004). Universalism and particularism in the Western world. Implications of basic value orientations for perspectives of democracy. Paper presented at the Third Interdisciplinary Conference "Democracy and Culture in the Transatlantic World", Maastricht, 27-30 October.

White, S. (1979). The USSR: Patterns of autocracy and industrialism. In A. Brown \& J. Gray (Eds.), Political culture and political change in Communist states (2nd ed., pp. 25-65). London and Basingstoke: MacMillan.

Wu, W., Weaver, D., \& Johnson, O. V. (1996). Professional roles of Russian and US journalists: A comparative study. Journalism \& Mass Communication Quarterly, 74(3), 534-548.

Wyman, M. (2000). Political culture and public opinion. In M. Bowker \& C. Ross (Eds), Russia after the Cold War (pp. 103-118). Harlow: Longman.

Zassoursky, Y. N. (1999). Open society and access to information: The role of Russian media. In $\mathrm{Y}$. $\mathrm{N}$. Zassoursky \& E. Vartanova (Eds.), Media, communications and the open society (pp. 27-37). Moscow: Faculty of Journalism, IKAR.

Zassoursky, I. I. (1999). Mass-Media vtoroi respubliki. Moscow: izd. Moskovskogo Universiteta.

Zimmerman, W. (1995). Synoptic thinking and political culture in post-Soviet Russia. Slavic Review, 54, 630641.

\section{About the Author}

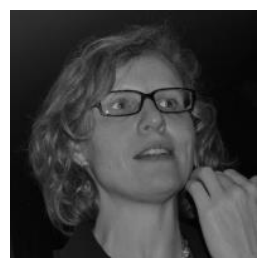

Dr. Hedwig de Smaele

Hedwig de Smaele is programme director of the master in Journalism at KU Leuven and a member of the Brussels Center for Journalism Studies. Areas of interest are among others media policy, journalism culture, democratization processes and political communication. Her Ph.D (2001) looks at the transition of mass media in Russia during the 1980s and 1990s. She has published in journals such as European Journal of Communication, Trends in Communication, and Javnost/The Public. 